\title{
Wab en de gemiste kans
}

\author{
Ruud Vergoossen
}

Valentijnsdag 2012 gaat de boeken in als de dag waarop de Tweede Kamer heeft ingestemd met de Wet op het accountantsberoep (Wab). Na de diepe dalen in de afgelopen decennia in de relatie tussen Koninklijk NIVRA en NO$\mathrm{vAA}$, lijkt het er dan toch uiteindelijk van te komen dat de liefde tussen beide beroepsorganisaties wordt bezegeld. De Wab voorziet het samengaan van NIVRA en NOvAA in de Nederlandse Beroepsorganisatie van Accountants (NBA) van een wettelijke basis.

So far so good - but then comes the poison arrow.

Hoewel ik volledig achter de fusie van NIVRA en NOvAA sta, ben ik niet tevreden over een belangrijk onderdeel van de Wab en ben ik verbolgen over de wijze waarop politiek Den Haag - in casu de Tweede Kamer - heeft geacteerd. Twee dingen:

1. Zij heeft de Wab gebruikt om - ondoordacht en in mijn optiek op oneigenlijke gronden - een aantal ingrijpende wijzigingen aan te brengen in de Wet toezicht accountantsorganisaties (Wta) die de uitoefening van het accountantsberoep direct raken en die volkomen los staan van de onderwerpen waar de Wab over gaat.

2. $\mathrm{Zij}$ heeft de boot gemist door niet een 'weeffout' uit de accountantswetgeving te halen die er nu bijna twintig jaar in zit en juist wel ligt op een van de onderwerpen waarover de Wab handelt, namelijk de opleiding tot accountant.

\section{Wat is er aan de hand?}

Door een aantal Tweede Kamerleden is de behandeling van de Wab aangegrepen om amendementen in te dienen die door een meerderheid van de Tweede Kamer zijn aanvaard. Het gaat onder meer om de volgende amendementen:

- Door Plasterk (PvdA), Irrgang (SP) en Braakhuis (GroenLinks) is een amendement ingediend dat moet leiden tot een scheiding van controle en advies bij organisaties van openbaar belang (OOB's), dat wil zeggen bij beursfondsen, banken en verzekeraars: "De accountantsorganisatie die wettelijke controles verricht bij een organisatie van openbaar belang, verricht naast controlediensten geen andere werkzaamheden voor die organisatie." Door de steun van de PVV is er een Kamermeerderheid voor dit amendement.
- Door Van Vliet (PVV) is er een amendement ingediend dat OOB's verplicht om na acht jaar te wisselen van de accountantsorganisatie die de wettelijke jaarrekeningcontrole uitvoert. Daarna moet er een afkoelingsperiode van twee jaar in acht worden genomen voordat dezelfde accountantsorganisatie weer de jaarrekening mag controleren. Door de steun van een aantal oppositiepartijen kan ook dit amendement bogen op een Kamermeerderheid.

- Door Plasterk, Van Vliet, Irrgang en Braakhuis is een amendement ingediend over het slechten van de zogeheten Chinese Walls binnen de Autoriteit Financiële Markten (AFM) tussen het toezicht op accountantsorganisaties en het toezicht op de financiële verslaggeving van ondernemingen met een beursnotering. Gezien de indieners van dit amendement - dat de uitwisseling van informatie tussen de toezichtafdelingen van de AFM mogelijk maakt - heeft het de steun van een Kamermeerderheid.

Bijzonder is dat genoemde amendementen zonder de steun van de regeringspartijen in de Tweede Kamer zijn aangenomen, een gevolg van de bijzondere politieke constellatie waarin Nederland met zijn minderheidskabinet op dit moment verkeert.

De Kamermeerderheid heeft geen boodschap aan het feit dat Nederland met name als gevolg van de eerste twee amendementen flink uit de pas gaat lopen met wat op dit moment internationaal gebruikelijk is. Belangrijker echter is nog dat er op Europees niveau wetgeving onder handen is die die amendementen zal overrulen. Eurocommissaris Barnier heeft immers een voorstel voor een Europese verordening (regulation) ingediend met betrekking tot de wettelijke jaarrekeningcontrole bij OOB's. Zodra de Europese Raad van Ministers en het Europese Parlement de verordening aanvaarden, heeft zij direct kracht van wet en is zij rechtstreeks van toepassing zonder tussenkomst van nationale wetgevers in de lidstaten. Dit in tegenstelling tot Europese richtlijnen (directives) die de lidstaten eerst in hun nationale wetgeving moeten incorporeren. Het is allerminst zeker of de verplichte kantoorroulatie het op Europees niveau wel gaat halen.

Ik vind de wijze waarop de meerderheid van de Tweede Kamer met dit gegeven omgaat onzorgvuldig. Het lijkt erop dat een aantal Kamerleden willens en wetens op het accountantsdossier wil 'scoren'. Het is te hopen dat de 
Eerste Kamer wel zorgvuldig te werk gaat, hetgeen zou betekenen dat zij het wetsontwerp inclusief amendementen terugstuurt naar de Tweede Kamer.

Het is betreurenswaardig dat de Tweede Kamer de behandeling van de Wab niet heeft gebruikt om de 'mismatch' die er op dit moment bestaat tussen de accountantsopleiding en de feitelijke beroepsuitoefening in de praktijk van met name de accountant-administratieconsulent (AA) weg te nemen. Het niet op elkaar aansluiten van 'theorie en praktijk' heeft alles te maken met de bevoegdheid van niet alleen de registeraccountant (RA), maar ook de AA om wettelijke jaarrekeningcontroles uit te voeren. De opleidingen tot RA en AA zijn daardoor - noodzakelijkerwijs beide gericht op de uitoefening van de wettelijke controlebevoegdheid. Door AA's wordt daar echter niet of nauwelijks gebruik van gemaakt. $\mathrm{Zij}$ treden op als adviseurs in het midden- en kleinbedrijf waar behoefte bestaat aan een breed opgeleide 'business coach' die de ondernemer bijstaat bij de dagelijkse bedrijfsvoering. In het grootbedrijf is er daarentegen juist behoefte aan specialisten, waaronder een accountant die de jaarrekening controleert.

Onder meer door de Commissie Eindtermen Accountantsopleiding (CEA) wordt dan ook gepleit voor differentiatie in de accountantsopleiding, waarbij in ieder geval onderscheid wordt gemaakt in opleidingen tot accountant die wel en die niet de bevoegdheid geven om wettelijke jaarrekeningcontroles uit te voeren. De ideale accountantsopleiding zou moeten beginnen met een gemeenschappelijke basisopleiding waarna vervolgens wordt gekozen voor profilering en verdergaande differentiatie. Vergelijk in de geneeskunde de hartchirurg die eerst de artsenopleiding heeft gevolgd. Alle accountants (RA's en AA's) volgen de basisopleiding waarna een profilering naar het verschaffen van zekerheid (assurance) of het optreden als financieel adviseur volgt. De behoefte aan assurance over de betrouwbaarheid van financiële informatie verbreedt zich in rap tempo naar assurance over de betrouwbaarheid van niet-financiële informatie, over risico's en over compliance. In het midden- en kleinbedrijf bestaat behoefte aan de accountant in de rol van financieel adviseur die kwaliteit toevoegt aan de interne en externe informatievoorziening. $\mathrm{Na}$ afronding van het assurance-profiel wordt gekozen voor een nadere differentiatie, waarvan de opleiding tot wettelijk controleur er een is. Het toesnijden van de accountantsopleiding op de daadwerkelijke beroepsuitoefening voorkomt maatschappelijke verspilling en draagt bij aan de kwaliteit van de dienstverlening door accountants. Dit in de ogen van velen ideale opleidingsmodel lijkt op dit moment echter niet (meer) haalbaar.

In de Wab wordt de bevoegdheid van AA's weliswaar enigszins ingeperkt doordat zij in de toekomst geen wet- telijke jaarrekeningcontroles bij OOB's meer mogen verrichten, maar dat zet weinig zoden aan de dijk. Het verschil in vakbekwaamheidseisen voor accountants die wel of niet bevoegd zijn om wettelijke jaarrekeningcontroles bij OOB's te verrichten, is minimaal.

Als 'second best' zou binnen de structuur van de Wab een groter onderscheid kunnen worden gemaakt in de wettelijke controlebevoegdheid van RA's en AA's en zouden de vakbekwaamheidseisen daarop afgestemd kunnen worden. Dat zou bijvoorbeeld op de volgende twee manieren kunnen:

1. door de wettelijke jaarrekeningcontrole bij grote ondernemingen (zoals gedefinieerd in Titel 9 BW 2) - net als bij OOB's - exclusief voor te behouden aan RA's.

2. door verruiming van de definitie van $O O B$ zodat ook grote ondernemingen daaronder vallen en/of (andere) organisaties met een publieke functie, zoals pensioenfondsen, energiebedrijven, vervoersbedrijven, universiteiten, hogescholen, gemeenten, provincies, ziekenhuizen.

Door CEA is bij de Tweede Kamer gepleit voor een amendement in een van de twee genoemde richtingen. Hoewel zij bij de regeringspartijen een gewillig oor vond, is er geen amendement uit voortgekomen. Dat is erg jammer, omdat de Wab de uitgelezen kans was om de accountantsopleiding meer te differentiëren en beter te laten aansluiten op de behoeften van met name het midden- en kleinbedrijf. Het was beter geweest als een aantal Tweede Kamerleden zijn 'scoringsdrift' in toom had weten te houden en zich had geconcentreerd op de onderwerpen waar de Wab zelf over gaat, waaronder de vakbekwaamheidseisen van accountants.

Het is een gemiste kans voor de Tweede Kamer. Wellicht dat zij in de rebound nog tot dit inzicht komt. Daarvoor is wel nodig dat de Eerste Kamer het wetsontwerp voor herbehandeling terugstuurt naar de Tweede Kamer. Ik ben razend benieuwd of dit daadwerkelijk gaat gebeuren. In mijn ogen is er bij de behandeling van de Wab in de Tweede Kamer sprake geweest van een onzorgvuldig proces. Het is de taak van de Eerste Kamer om erop te letten dat wetten in ons land op een zorgvuldige wijze tot stand komen.

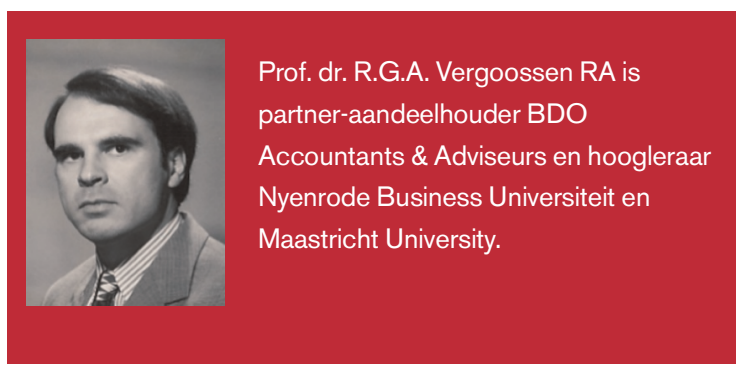

